\title{
Implications of Covid-19 on Auditor's Reporting
}

\author{
Mila Reyes \\ mila.reyes@president.ac.id \\ Accounting Program Study, Faculty of Business, \\ President University, Cikarang, Indonesia \\ Andrianantenaina Hajanirina \\ hajanirina@president.ac.id \\ Accounting Program Study, Faculty of Business, \\ President University, Cikarang, Indonesia \\ Gatot Imam Nugroho \\ gatotnugroho@president.ac.id \\ Accounting Program Study, Faculty of Business, \\ President University, Cikarang, Indonesia
}

\begin{abstract}
Twenty years ago, nobody will ever think that the world will experience what we are experiencing right now. The whole world had been put in uncertainty due to pandemic which started from the city of Wuhan, China. This pandemic called COVID-19 had affected everyone's life including many companies in Indonesia. It has impact on audit quality. Matters are analyzed through input/output based on Francis (2011) and Knechel (2010). This research adopts desk study method to investigate the impact of COVID-19 to audit quality. It suggests the improvement of the regulations (time, and fee), the auditor's matters (experience, routine, and client). Quality can be based not only by the auditing report as the product from the activity, but from the engagement from the output of this report for long term horizon.
\end{abstract}

Keywords: Covid-9; audit opinion; matters; audit quality

\begin{abstract}
Abstrak
Dua puluh tahun yang lalu, tidak ada yang pernah berpikir bahwa dunia akan mengalami apa yang kita alami saat ini. Seluruh dunia dilanda ketidakpastian akibat pandemi yang dimulai dari kota Wuhan, China. Pandemi COVID-19 ini telah mempengaruhi kehidupan semua orang termasuk banyak perusahaan di Indonesia. Kejadian ini berdampak pada kualitas audit. Analisis dalam investigasi mengacu pada hasil input / output berdasarkan Francis (2011) dan Knechel (2010). Penelitian ini menggunakan metode desk study untuk mengetahui dampak COVID-19 terhadap kualitas audit. Disimpulkan bahwa perlunya perbaikan peraturan (waktu, dan biaya), dan solusi pada permasalahan auditor (pengalaman, rutinitas, dan klien). Kualitas tidak hanya didasarkan pada laporan audit sebagai produk dari aktivitas, tetapi dari keterlibatan dari output laporan untuk jangka panjang.
\end{abstract}

Kata kunci: COVID-19; opini audit; masalah; kualitas audit 


\section{INTRODUCTION}

The COVID-19 pandemic changes many companies' environmental contingency plan and strategies. It is analyzed that the year 2020 and especially the first quarter shows great challenge for any companies around the world. Besides, governments handle the situation by regulating the movement, the activities, and any human gathering or direct meeting. It is done through different aspects, partial lock down, complete lock down, or some more relaxed policies. All impact on business activities for any industries (Deloitte, 2020).

For the case of Indonesia, the companies represented as the public accountants firms clients suffer from the crisis as the economic factors tend to be worst. It was reported that the GDP rate tended to be negative until 2021. It impacts all industries apart from telecommunication and the alike that can still operate and even realize positive income.

Table 1. Indonesia GDP growth projection

\begin{tabular}{|c|c|c|c|c|c|c|}
\hline Item & & Note & 2019 & 2020 & 2021 & 2022 \\
\hline Real GDP & & $\%$ change (annual) & 5.0 & 0.0 & 4.8 & 6.0 \\
\hline CPI & & $\%$ change (annual) & 2.8 & 2.6 & 2.8 & 3.0 \\
\hline $\begin{array}{l}\text { Current } \\
\text { balance }\end{array}$ & account & $\%$ of GDP & -2.7 & -1.9 & -2.0 & -2.1 \\
\hline $\begin{array}{l}\text { Government } \\
\text { balance }\end{array}$ & budget & $\%$ of GDP & -2.2 & -6.3 & -4.1 & -3.1 \\
\hline
\end{tabular}

Source: The World Bank (2020)

As reported from this table, the current account balance shows negative result from $-2.7 \%$ of the GDP in 2019 (that the outbreak started), $-1.9 \%$ in 2020, -2.0\% for the year 2021 and is estimated to be $-2.1 \%$ for the year 2022. The government budget balance suffers from deficit year by year $-2.2 \%$ of the GDP (2019), with worse condition form 2020 (-6.3\%) and cannot recover till 2022 by $-3.1 \%$ of the GDP. In fact, these results and projections reflect the prospects of all industries where the firms are classified. The firms need to adapt with this unfortunate economic condition, by which public trust is necessary to be highlighted. Thus, disclosing important information to the public is important. This practice is supported by the audit quality amidst the pandemic of COVID-19. However, serious concern on the trade-off between the audit reporting and the firm image is somehow queried.

Even though, companies that have gone public are required to publish financial reports that have been audited by an independent party annually (auditor), however some malpractices are still recently exposed (the case of Garuda Indonesia and BDO Tanubrata, Jiwasraya and $\mathrm{PwC}$, etc). Financial reports are expected to provide information that is fair, trustworthy and easy for users to understand. In order to provide reasonable, trustworthy and easy to understand information, it is necessary to have procedures for auditing financial statements carried out by a certain Public Accounting Firm (KAP) through an independent auditor.

The violating of the accounting standard and the audit principles are somehow lead the fraudulent acts. These are not normally human error but there are some causes of the frauds. It can be explained by the triangle of fraud (Cressey, 1950) as the opportunity, rationalization and the financial pressure. 


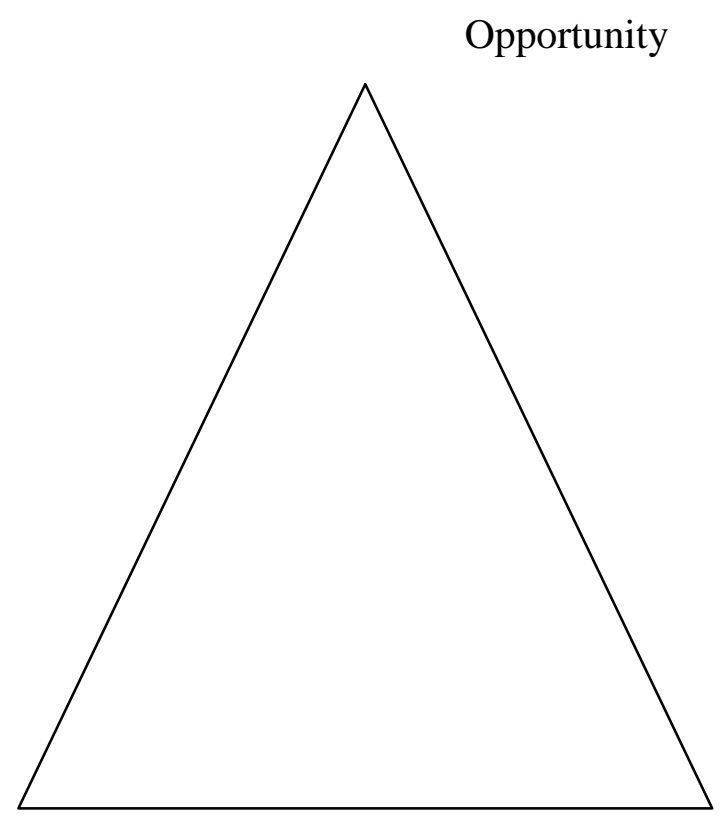

Financial pressure

Rationalization

Figure 1. Triangle of fraud

From this challenging situation, many companies realize downtrend on the financial reports, mostly the annual income. This financial pressure, leads some of the managers to look for any shortcut to keep the company survive. The investors need positive sign (signaling theory aspect, Spence $(1973,2002)$ which leads to improve the market position of each company. In fact, managers, in the detriment of the financial failure and the distrust by the public tend to use any means to increase the value of the firm even by income smoothing practice.

Table 2. Total comprehensive profit/ (loss) for the year

\begin{tabular}{|c|c|c|c|}
\hline Companies & 2020 & 2019 & 2018 \\
\hline Garuda Indonesia (Persero) Tbk & & $\$ 91,578,494$ & $\$(259,881,456)$ \\
\hline PT Hotel Sahid Jaya & & $\operatorname{Rp}(12,980,686,229)$ & Rp1,222,066,873 \\
\hline International Tbk & & & \\
\hline PT Astra Agro Lestari Tbk & $\begin{array}{c}\text { Rp467,253 } \\
\text { (millions) }\end{array}$ & $\begin{array}{l}\operatorname{Rp}(5,223) \\
\text { (millions) }\end{array}$ & \\
\hline
\end{tabular}

Source: Annual report of the firm

Viewed from Table 2, for the recent three years (2018 to 2020), some companies suffer from loss during certain year(s). Garuda Indonesia (Persero) Tbk realized $\$(259,881,456)$ loss from 2018. This is a privileged Indonesian airways, located in Soekarno-Hatta International Airport that operates domestic and international routes including USA (New York), Australia (Adelaide), South Africa (Johannesburg), Europe (Paris and others), Japan (Fukuoka) etc.

As for the hospitality industries, an example is, PT Hotel Sahid Jaya International Tbk, that resulted in loss for the financial report of 2019 by, $\operatorname{Rp}(12,980,686,229)$. This comprehensive loss is in the detriment of the COVID-19 for 2020 to 2021. 
Apart from the triangle of fraud that might cause the managers to be induced in scandals involving audit practice questioned, the fraud diamond is also derived from Wolfe and Hermanson (2004), known as the fraud diamond theory.

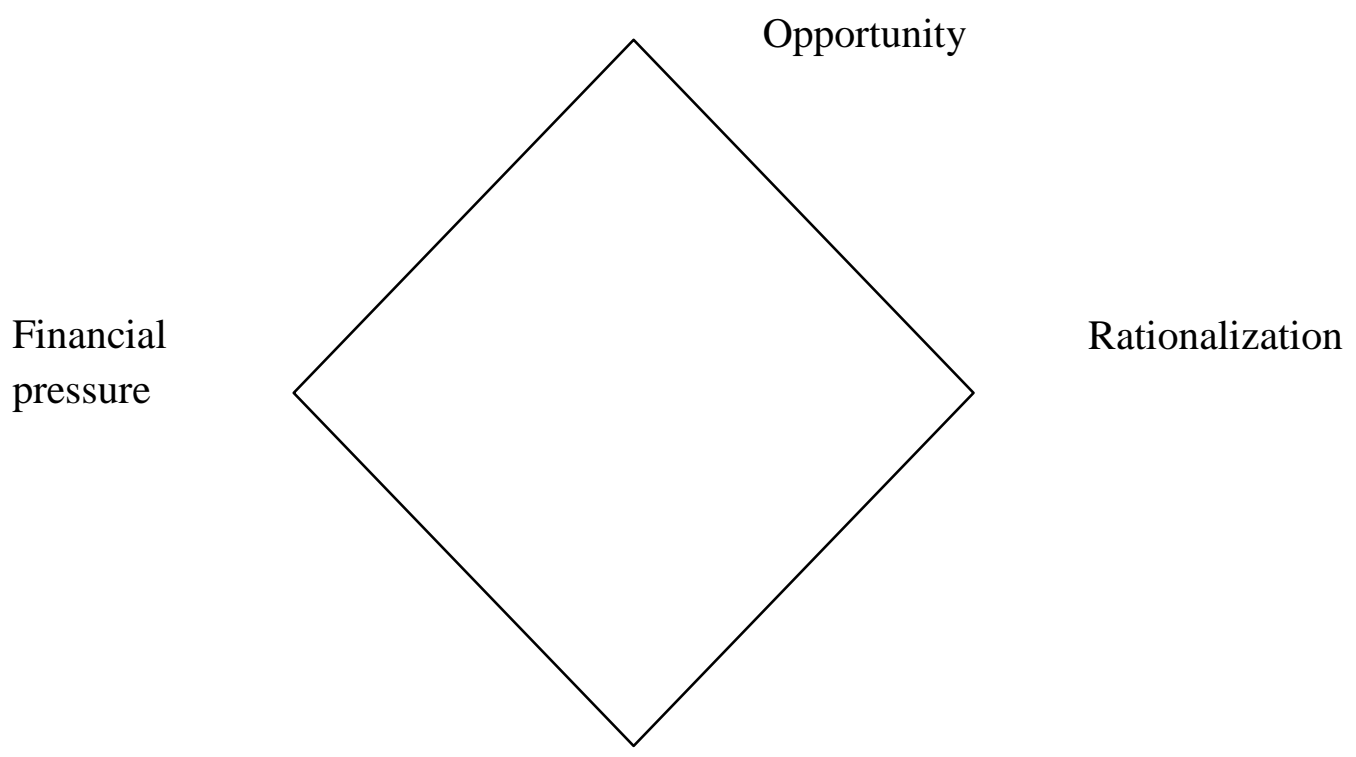

Capacity

Figure 2. The Fraud diamond

Apart from what is initiated by Cressey (1950), Wolfe and Hermanson (2004) add the capacity of the individual to commit fraud. This capacity can be explained by taking advantage to the loophole on the regulations, such as, those in accounting standard, and government regulations on taxes and corporations. Managers have the high position to lead the general policy of the company for short and long terms. That authority provides for the managers to act in their interest (agency problem, Jensen and Meckling (1976)) even to keep the income seems positive (earnings management) to attract investors.

Crucially, these economic turbulence and market uncertainty can affect public confidence on the financial performance of the company. Therefore, quality audit is necessary to ensure the safety of the users of the financial information.

Yet, so huge is the impact of the COVID-19 toward the company economic condition, even that might lead the managers to act absurdly, special treatments in terms of regulations (accounting regulations) are not yet available to keep auditing procedures going well and provide for the companies allegiance regarding its financial concerns.

\section{LITERATURE REVIEW}

The one who safeguards the public trust is auditor. The main task an auditor needs to maintain is the principles, the ethics, and the enforced regulation qualifying the professionalism of the accounting firms. As explained before, the triangle fraud theory (Cressey, 1950) and the diamond fraud theory (Wolfe \& Hermanson (2004)), managers might indulged auditors to act unconsciously. This is done to maintain the positive income trend of the company (as in detriment of the COVID-19 negative impacts) to attract the investors. However, this harms audit quality and creates public scandals. Audit quality is then questioned about its evidence.

Defining or assessing the audit quality differs from the one who analyze or conduct the auditing report. According to Knechel, et al. (2013), auditor, regulator and public have 
different angles to assess the quality of the audit report. Auditor might satisfy by referring to the accounting standard and the auditing procedures to asses a client before providing appropriate opinion.

Through Knechel (2010), audit quality can be evaluated based on some characteristics including the "matters" which are: incentives, uncertainty, uniqueness, process and professional judgment. The output qualifies the audit report for long term horizon.

Table 3. Output "matters" of the audit quality

\begin{tabular}{ll}
\hline "Matters" characteristics & Implications \\
\hline incentives & Audit $\rightarrow$ economic response to risk \\
uncertainty & Audit outcome $\rightarrow$ report, but \\
& Audit report outcome $\rightarrow$ uncertain \\
& (engagement risk) \\
uniqueness & Engagement in audit is unique based on \\
& clients characteristics \\
& Audit $\rightarrow$ clients' \\
process & Audit $\rightarrow$ systematic activity \\
professional judgment & Audit $\rightarrow$ knowledge, skill, experience
\end{tabular}

Source: Adapted from Knechel (2010)

Based on Table 3, audit report is just the output of the auditing activities (process matters), it can be directly understood by users. However, its output (the audit report) cannot be estimated in advance. The risk associated by giving such opinion is not materialistically contracted explicitly. If under pressure (the managers for instance), by means of audit compromise, earning management can be used (either through audit shopping or the audit tenure friendship). The output suggested by Oktavianto and Suryandari (2018) to measure audit quality is by evaluating the audit complexity since it reduces the audit quality. Yet, it does not deal with the engagement risk from the report.

As for Francis (2011), the engagement becomes the main focus of concern. Output form audit such as:

Table 4. Engagement in audit by input/output

\begin{tabular}{ll}
\hline Input & Output \\
\hline $\begin{array}{l}\text { Experience Competence } \\
\text { and training) }\end{array}$ & $\begin{array}{l}\text { Revenue Information } \\
\text { (fee of service, industries, geographic regions) }\end{array}$ \\
Workload & $\begin{array}{l}\text { Independence matters (information about } \\
\text { independence violations) }\end{array}$ \\
Leverage (ratio of partner staff) & $\begin{array}{l}\text { Restatement and Inspection Results } \\
\text { Client Acceptance and Dismissal (information } \\
\text { on new clients and cases where dismissed) }\end{array}$
\end{tabular}

Source: Adapted from Francis (2011) 
This can explain the engagement matters that need to be considered after the audit report is available. The audit quality requires for instance the independence based on the workload. Since complexity impacts on audit quality as in Oktavianto and Suryandari (2018).

\section{RESEARCH METHOD}

This research is based on the desk study method exploring the implications of pandemic COVID-19 on the auditor's report based on extent theories and evidence (Knechel (2010), Francis (2011) and Knechel, et al. (2013)). Besides, practice in the field is analyzed to support the evidence.

For the case of Indonesia, the outbreak of COVID-19 forced auditors to work from home since March, 2020. Audit companies continue their audit relying more on digital programs, using internet, and other sources to help them to adapt to the government program of social distancing. This prompts the researcher to study the implications of the current situation on the auditor's report which is the basis for the users in making decision about the company.

Given the importance of auditing to ensure the quality of the financial information, this study aims to explore the implications of pandemic COVID-19 on the audit quality. It is then associated with the input/output matters to qualify the audit report.

\section{ANALYSIS AND DISCUSSIONS}

Table 5. Output "matters" of the audit quality

\begin{tabular}{|c|c|c|}
\hline $\begin{array}{l}\text { "Matters" } \\
\text { characteristics }\end{array}$ & Implications & Evidence \\
\hline incentives & $\begin{array}{l}\text { Audit } \rightarrow \text { economic response to } \\
\text { risk }\end{array}$ & $\begin{array}{l}\text { However, audit fee might harm } \\
\text { the quality of audit report } \\
\text { (Homayoun } 1 \& \text { Hakimzadeh, } \\
2017 \text { ) } 30 \text { family and } 30 \text { non } \\
\text { family firms is considered and } \\
\text { found that family firms pay less } \\
\text { fee to auditor. } \\
\rightarrow \text { fee matters }\end{array}$ \\
\hline uncertainty & $\begin{array}{l}\text { Audit outcome } \rightarrow \text { report, but } \\
\text { Audit report } \\
\text { outcome } \rightarrow \text { uncertain } \\
\text { (engagement risk) }\end{array}$ & $\begin{array}{l}\text { Regulations on engagement risk } \\
\text { require specific period of time } \\
\text { and characteristics. } \\
\rightarrow \text { time matters } \\
\rightarrow \text { regulations matters }\end{array}$ \\
\hline $\begin{array}{l}\text { Uniqueness } \\
\text { workload }\end{array}$ & $\begin{array}{l}\text { Engagement in audit is unique } \\
\text { based on clients characteristics } \\
\text { Audit } \rightarrow \text { clients' }\end{array}$ & $\begin{array}{l}\text { Audit tenure, even regulated by } \\
\text { the institutions, shopping and } \\
\text { friendship persist. } \\
\rightarrow \text { clients matters }\end{array}$ \\
\hline $\begin{array}{l}\text { Process } \\
\text { leverage }\end{array}$ & Audit $\rightarrow$ systematic activity & $\begin{array}{l}\rightarrow \text { Professionals, junior, senior } \\
\text { auditors perform their activity } \\
\text { based on certain mechanism, } \\
\text { however, overconfidence ruins } \\
\text { the activity, skepticism is } \\
\text { important. } \\
\rightarrow \text { routine matters }\end{array}$ \\
\hline
\end{tabular}




\begin{tabular}{lll}
\hline $\begin{array}{l}\text { professional } \\
\text { judgment }\end{array}$ & $\begin{array}{l}\text { Audit } \rightarrow \text { knowledge, } \\
\text { experience }\end{array}$ & skill, \\
experience & $\begin{array}{l}\text { Some accounting firms recruit } \\
\text { trainees and engage them high } \\
\text { level of task. } \\
\text { competence }\end{array}$ & $\begin{array}{l}\rightarrow \text { experience matters } \\
\text { technical }\end{array}$ \\
resources & & \\
\hline
\end{tabular}

Source: Adapted from Francis (2011), Knechel (2010), authors

\section{Effect of COVID-19 in audit quality}

New matters are then derived from these outputs either during the normal conditions as well as pre/amidst/post COVID-19 pandemic. Work from home (whf) characterizes the new normal way of life added with the use of mask, hand washing, and social distancing as health protocol known as $3 \mathrm{M}^{1}$ in Indonesia. It does not impact on the auditing activity. What matters are, the following new matters including: fee, time, regulations, client, routine, and experience to audit quality.

\section{Fee matters, time and regulations matters}

Similar to the COVID-19 event, Ettredge, et al. (2014) predicted the audit quality based on the fee to auditors. As concluded for the time period of 2007 to 2009 (global financial crisis), audit fee has negative impact on audit quality. In light of difficult period including global financial crisis, COVID-19 pandemic, fee is important factor to predict professional activities including auditing process. However, companies suffer from negative income; thus, they tend to reduce all possible cost with no exception for the audit fee. It supports the evidence of triangle of fraud theory and the fraud diamond theory (Cressey (1950) and Wolfe \& Hermanson (2004)).

Oh the other hand, regulations or standards specified to handle such undiversifiable risk still not enforced. PSAK needs to adapt more on these matters.

\section{Client matters, routine matters and experience matters}

The COVID-19 pandemic affects worldwide company financial performance. In the case of Indonesia, the big 4 accounting firms use their principles to certify professionally any clients they are contracted with. Yet, the clients tend look for any reputable firms that can fit for their needs. There must be specific attention while auditing clients amidst such a global crisis. Routine done by accounting firms do not capitalize the change of the firm practice during the pandemic. The use of trainees, and junior auditors, if massive, ruins the audit quality since they just rely on routine not experiences.

\section{CONCLUSION/RECOMMENDATION}

Maintaining audit quality is crucial especially during the COVID-19 pandemic due to its catastrophic impact on company's financial income and the core business in general. Malpractices emerge caused by the condition as supported by the triangle of fraud theory and the fraud diamond theory. Thus, financial pressure leads managers and auditors to compromise the auditor independency. Thus, this analysis suggests new matters to be focused more including: fee, time, regulations, client, routine, and experience to audit quality. These are derived from Fancis (2010) and Knechel (2010).

\footnotetext{
${ }^{1}$ Memakai masker, mencuci tangan, and menjaga jarak

DOI: http://dx.doi.org/10.33021/jaaf.v\%vi\%i.1461
} 
Laws and regulations need to adapt with each environmental conditions including the global pandemic such as COVID-19. It is hoped to enhance managerial capacity and experience for any managers to achieve the objective for short and long run in order to be always survived. Efficiency of the general and administrative expenses are needed to be reduced including audit fee.

On the other hand, regardless of whether the auditor plans to rely on the operating effectiveness of controls, they are still required to obtain an understanding of internal control relevant to the audit. This understanding (including the design and implementation of any changes in controls relevant to the audit) supports the identification of potential misstatements and factors that affect the risks of material misstatement.

With remote working arrangements and reduced personnel, controls activities relating to authorization, performance reviews, segregation of duties, and physical controls may be at risk of breaking down or being circumvented. An understanding of controls relevant to the audit, including control changes and new controls, may be more challenging in the current environment. Many auditors and client personnel are working remotely and will not be able to speak with their clients face-to-face, or physically inspect documents and reports, or observe the application of specific controls.

When using information produced by the entity, the auditor is required to evaluate whether the information is sufficiently reliable (i.e., complete, accurate, precise, and detailed) for its purposes. Although the auditor is not responsible for authenticating the documents themselves, the auditor needs to exercise professional skepticism when considering their reliability as evidence. For example, the auditor needs to consider the reliability of scanned or otherwise reproduced source documents and whether the document is faithful in form and content to the original.

Another factor that has to be considered is the assessment of the companies' going concern. In 2020 many companies implemented closures and reduced of sales had been a trend. This situation added to the difficulties by auditors to assess the ability of the company to continue as going concern, or whether this current situation can still suggest the financial statements prepared is still based on the principle of going concern.

In this time of uncertainties, CFO's and auditor should work together. CFOs should not forget that in the recent past there has been increased limelight/inquiries into professional audit services - \& statutory auditor have been under fire for instances of fraud, mismanagement, corporate failure, and professional misconduct. So, if auditor is being slightly skeptical with the information or explanation being provided, and is seeking a higher level of assurance through larger population testing, CFO's should be more cooperative and help the auditor to have the full picture of the company.

Furthermore, audit reports issued will be used by different parties, therefore needs to be of good quality. Auditors and CFO's must have the same mission when it comes to audit reporting to be consumed by the public to ensure that in spite of difficulties and hurdles the financial reports issued is still reliable and provide assurance about the correct situation of the company.

\section{REFERENCES}

Spence, M. (1973). Job Market Signaling. The Quarterly Journal of Economics, 87(3), 355. https://doi.org/10.2307/1882010.

Spence, M. (2002). Signaling in retrospect and the informational structure of markets. American Economic Review, 92: 434-459

Albitar, K., Gerged, A.M., Kikhia, H. and Hussainey, K. (2020). Auditing in times of social distancing: the effect of COVID-19 on auditing quality, International Journal of

DOI: http://dx.doi.org/10.33021/jaaf.v\%vi\%i.1461 
$\begin{array}{llll}\text { Accounting \& Information } \quad \text { Management, } & 29(1), \quad 169-178 .\end{array}$ https://doi.org/10.1108/IJAIM-08-2020-0128

Hay, D., Shires, K. and Van Dyk, D. (2021). Auditing in the time of COVID - the impact of COVID-19 on auditing in New Zealand and subsequent reforms, Pacific Accounting Review, https://doi.org/10.1108/PAR-09-2020-0155

Francis, J.R. (2011), "A framework for understanding and researching audit quality", Auditing: A Journal of Practice andTheory, 30(2), 125-152.

Knechel, W. R., Krishnan, G. V., Pevzner, M., Shefchik, L. B., \& Velury, U. K. (2013). Audit quality: Insights from the academic literature. Auditing: A Journal of Practice, 32(Supplement 1), 385-421.

The World Bank (2020), Indonesia economic prospects the long road to recovery

Jensen, M. C., \& Meckling, W. H. 1976. Theory of the firm: Managerial behavior, agency costs and ownership structure. Journal of Financial Economics, 3: 305-360. 